\title{
Gospodarka współdzielenia - pojęcie, źródła, potencjał
}

\section{Streszczenie}

W artykule zaprezentowano przegląd definicji gospodarki współdzielenia. Podkreślono rolę dostępu do dóbr i usług, który w coraz większym stopniu zastępuje posiadanie. Przedstawiono również źródło pojęcia gospodarki współdzielenia oraz główne kategorie jej podziału. Gospodarka współdzielenia została potraktowana jako alternatywny model konsumpcji, którego celem jest zwiększenie efektywności wykorzystywanych zasobów i tworzenie nowej wartości dla społeczeństwa. Jest to możliwe w dużej mierze dzięki rewolucji cyfrowej, która dostarcza odpowiednich narzędzi, dzięki nowej jakości w relacjach międzyludzkich, a także zwiększającej się świadomości społecznej. Celem pracy jest przegląd literatury przedmiotu oraz zwrócenie uwagi na potrzebę odróżnienia gospodarki współdzielenia od rozwiązań nastawionych na zysk.

Słowa kluczowe: gospodarka współdzielenia, ekonomia współdzielenia, hiperkonsumpcja, homo collaborans, zrównoważony rozwój.

Klasyfikacja JEL: D11, D23, M13, O31.

\section{Wprowadzenie}

Gospodarka współdzielenia i wspólna konsumpcja to zagadnienia coraz częściej poruszane we współczesnym dyskursie nie tylko medialnym, ale również naukowym. W opracowaniach naukowych dominuje podejście, według którego gospodarka współdzielenia to alternatywny model konsumpcji, stawiający

Barbara Sztokfisz, Uniwersytet Ekonomiczny w Krakowie, Studia Doktoranckie Wydziału Ekonomii i Stosunków Międzynarodowych, ul. Rakowicka 27, 31-510 Kraków, e-mail: basia. sztokfisz@gmail.com 
w centrum dostęp do danego dobra bez konieczności jego posiadania [Belk 2014, Ozanne i Ballantine 2010, Hamari, Sjoklint i Ukkonen 2015, Lamberton i Rose 2012, Bardhi i Eckhardt 2012]. Tymczasowy dostęp jest podstawą dzielenia się, które umożliwia bardziej efektywne wykorzystanie zasobów. Głęboka zmiana społeczna w tym zakresie oraz towarzysząca jej rewolucja cyfrowa sprawiły, że posiadane dobra przestały być traktowane jako odzwierciedlenie tożsamości jednostki, co może świadczyć o wkroczeniu w erę post-ownership [Belk 1988, 2007, 2013 i 2014]. Nie bez znaczenia są zaufanie pomiędzy użytkownikami, reputacja budowana w sieci [Schor 2014], a także nowa jakość społeczna tworzona pomiędzy zupełnie obcymi sobie osobami [Belk 2010 i 2014, Benkler 2005]. Podkreśla się także rolę nowych technologii, które zmniejszają znacznie koszty transakcyjne, czynią możliwym dzielenie się wcześniej niedostępnymi zasobami [Sundararajan 2014, Benkler 2005, Belk 2013] oraz tworzą siatkę powiązań pomiędzy indywidualnymi uczestnikami rynku [Gansky 2010]. Coraz częściej poruszane są także kwestie dotyczące przepisów prawnych, które nie nadążają za pojawiającymi się nowymi technologiami i ich możliwościami [Schor 2014, Petropoulos 2017, Benkler 2005, Codagnone i Martens 2016]. Badacze wskazują także na duży potencjał gospodarki współdzielenia, jeśli chodzi o bardziej efektywne wykorzystanie zasobów oraz zrównoważony rozwój [Heinrisch 2014].

Głównym celem artykułu jest usystematyzowanie pojęć związanych z sharing economy, a także wskazanie cech decydujących o zaliczeniu konkretnych rozwiązań do tej formy gospodarowania. Sharing economy, jaką znamy dzisiaj, jest pojęciem bardzo szerokim i nieostrym. Aby rozstrzygnąć toczące się spory pomiędzy jej zwolennikami a krytykami, należy dokonać kategoryzacji. Zgodnie z przyjętą tezą wyjaśnienie istoty sharing economy wymaga odróżnienia właściwej gospodarki współdzielenia, której głównym założeniem jest brak nastawienia na zysk, od rozwiązań wykorzystujących jedynie jej elementy.

\section{Czym jest sharing economy?}

Idea sharing economy stanowi wciąż wyzwanie dla współczesnych badaczy nauk społecznych. Jej hybrydowy charakter oraz kompleksowość sprawiają, że bardzo trudno jest wskazać teorię (czy w ekonomii głównego nurtu, czy też wśród współczesnych teorii przedsiębiorstw), która możliwie najpełniej tłumaczyłaby „dzielenie się". Gospodarka współdzielenia i oparte na niej rozwiązania podważają jedno z głównych założeń ekonomii neoklasycznej, znane od momentu opublikowania przez A. Smitha traktatu pt. Badania nad naturq i przyczynami bogactwa narodów, a mianowicie założenie homo oeconomicus. Ludzie, którzy wybierają dzielenie się, w znacznie mniejszym stopniu wspierają wzrost gospodarczy niż 
ci, którzy wybierają posiadanie. Decydując się na tego typu konsumpcję, często świadomie odrzucają rozwiązania optymalne na rzecz wyższych w ich mniemaniu wartości, takich jak zrównoważony rozwój, przeciwstawienie się rozrzutnemu gospodarowaniu zasobami oraz zwiększenie efektywności swojej konsumpcji przez zakup jedynie korzyści, jakie daje dany produkt, bez konieczności jego posiadania na własność. Posiadanie zdaniem coraz większej liczby konsumentów stanowi źródło niepotrzebnych obowiązków. Kluczowy staje się dostęp do danego produktu czy usługi, stąd też w języku angielskim zjawisko to bywa również nazywane access based consumption [Belk 2014, s. 1595]. Rozwiązania oparte na idei współdzielenia nie mogłyby odnieść sukcesu bez takich cech kapitału społecznego jak zaufanie i otwartość. Oparte na nich relacje międzyludzkie są podstawą transakcji między uczestnikami oraz stanowią fundament powodzenia rozwiązań opartych na takiej formie gospodarowania.

W języku polskim pojęcie sharing economy funkcjonuje jako ekonomia współdzielenia lub ekonomia współpracy. Ze względu na znaczenie terminu economy w języku angielskim, z którego pojęcie to się wywodzi, bardziej trafne wydaje się jednak określenie „gospodarka”. Dlatego też w artykule przyjęto tłumaczenie gospodarka współdzielenia. Niemniej jednak trzeba zaznaczyć, że wymienione określenia funkcjonują w polskiej literaturze przedmiotu równolegle i powinny być traktowane jako synonimy. W języku angielskim oprócz sharing economy występują również terminy: collaborative economy, gig economy, on-demand economy czy peer economy [Petropoulos 2017, s. 2].

Istnieje wielu zwolenników podlądu, że gospodarka współdzielenia w zasadzie nie jest niczym nowym. Powołują się oni na argument, że ludzie tak naprawdę dzielili się od zawsze, a wzrost popularności tego pojęcia to jedynie rezultat działań marketingowych wielkich korporacji. Biorąc pod uwagę cechy gospodarki współdzielenia obserwowane obecnie, można jednak zauważyć, że nie jest ona zwykłym dzieleniem się. Spotkać można różne definicje gospodarki współdzielenia, jedne są wąskie i szczegółowe, inne bardziej ogólne. Sam termin „wspólna konsumpcja” (collaborative consumption) pojawił się już w latach 70. ubiegłego wieku w pracy pt. Community Structure and Collaborative Consumption M. Felsona i J Spaetha [1978]. Oparli się oni w dużej mierze na opracowanej w latach 50. XX w. przez A. Hawleya teorii dotyczącej struktury wspólnoty i występujących w niej współzależności. Zgodnie z podejściem behawioralnym potraktowali wspólną konsumpcję jako akt korzystania z dóbr i usług razem z innymi osobami. Do wspólnej konsumpcji badacze zaliczają nawet takie czynności jak jedzenie obiadu z rodziną, a analizowane środowiska to przede wszystkim gospodarstwa domowe, praca oraz szkoła. Autorzy wskazują także na bardzo istotną rolę rutyny dnia codziennego oraz otoczenia, w której odbywa się konsumpcja. To właśnie czynnik czasowy oraz społeczny mają według nich kluczowe znaczenie dla wspólnej konsumpcji. Współ- 
występowanie potrzeb jednostek sprawia, że dążą one do stworzenia okoliczności, w których zwiększa się prawdopodobieństwo wspólnej konsumpcji. Współczesne podejścia do omawianego zjawiska znacznie wykraczają poza przyjęte w latach 70 . przez M. Feslona i J. Spaetha. Niemniej jednak ich praca powinna stanowić punkt wyjścia badań związanych zarówno ze wspólną konsumpcją, jak i gospodarką współdzielenia.

Analizę pojęcia sharing economy rozpoczniemy od odpowiedzi na pytanie, czym jest dzielenie się. Akt dzielenia się to czynność polegająca na udostępnianiu posiadanych przez nas zasobów innym, a także na przyjmowaniu przez nas samych zasobów niebędących naszą własnością [Belk 2007, s. 126]. Należy również odróżnić dzielenie się, w którym występuje transfer praw własności, od udostępnienia danego zasobu na z góry określony czas [Belk 2014, s. 1596]. Y. Benkler [2005] podkreśla społeczne znaczenie dzielenia się, według autora wielce niedoceniane, będące trzecim elementem organizacji produkcji (obok rynków i państwa), ściśle związanym z nowymi technologiami (darmowe oprogramowanie, technologie mobilne, peer-to-peer ${ }^{1}$ ).

Wychodząc od definicji dzielenia się, będącego podstawą sharing economy, należy przejść do znaczenia pojęcia gospodarki współdzielenia. J. Hamari, M. Sjoklint i A. Ukkonen [2015, s. 1] uważają, że gospodarka współdzielenia to formy aktywności oparte na rozwiązaniach peer-to-peer, polegające na udostępnianiu, otrzymywaniu oraz dzieleniu się dostępem do dóbr oraz usług, koordynowane przez internetowe platformy oparte na społeczności użytkowników. Według G. Petropoulosa [2017, s. 1-3] gospodarka współdzielenia polega na kojarzeniu ze sobą użytkowników online, którzy chcą dzielić się ze sobą dobrami i usługami. Za pomocą platformy będącej pośrednikiem strona podażowa (posiadająca nadmiar któregoś z zasobów) spotyka się ze stroną popytową. A. Sundararajan [2014] wskazuje trzy elementy, z których składa się gospodarka współdzielenia; są nimi: platformy, przedsiębiorcy oraz konsumenci. Przedsiębiorcy i konsumenci to tzw. peers. Platforma, stanowiąca bardzo istotny element, służy do pobierania prowizji, dokonywania opłat za dobra i usługi, a także jest miejscem budowania reputacji społeczności internetowej.

Analizując sharing economy, badacze bardzo często dokonują jej podziału. J. Schor [2014] podaje cztery główne kategorie, które obejmuje gospodarka współdzielenia; są to:

${ }^{1}$ P2P, czyli peer-to-peer (każdy z każdym) jest siecią komputerową, która umożliwia komunikację swoich użytkowników na równych zasadach. Każdy korzystający z tego rodzaju internetowej aplikacji może w dowolnej chwili zainicjować połączenie. Struktura P2P jest płynna, czyli zależna od liczby zalogowanych osób i nie posiada centralnego serwera (www.techopedia.com/ definition/25777/peer-to-peer-network-p2p-network, data dostępu: 2.04.2017). 
1) recyrkulacja towarów,

2) zwiększenie wykorzystania aktywów trwałych,

3) wymiana usług,

4) udostępnianie aktywów produkcyjnych.

Do pierwszej kategorii należą platformy służące do wymiany dóbr pomiędzy indywidualnymi uczestnikami rynku. Zwiększenie popularności tego typu serwisów wynika z rosnącego importu tanich dóbr konsumenckich (głównie z krajów azjatyckich), a co za tym idzie - rozprzestrzeniania się niechcianych przedmiotów i poszukiwania na nie rynków zbytu. J. Schor podaje wiele przykładów platform należących do tej kategorii. Są to m.in.: eBay, Craiglist, ThredUp, Freecycle, Yerdle czy Swapstyle ${ }^{2}$. Druga kategoria obejmuje wykorzystanie już istniejących zasobów w sposób bardziej efektywny. Pionierem na rynku był amerykański Zipcar, oferujący wynajęcie samochodu na godziny. Następnie pojawiły się takie firmy jak Uber czy Lyft oraz związane z dzieleniem przestrzeni mieszkalnej Couchsurfing oraz Airbnb. Trzecia kategoria odnosi się do wymiany usług. Jedną z najbardziej znanych platform jest Task Rabbit, na której można zgłosić potrzebę na wykonanie jakiegoś zadania (np. związanego z obowiązkami domowymi), a zarejestrowani użytkownicy platformy zgłaszają się do jego wykonania za zaproponowaną zapłatę. Ostatnia, czwarta kategoria związana jest bardziej ze stroną produkcyjną niż bezpośrednim popytem kreowanym przez konsumentów. Mieszczą się w niej przestrzenie coworkingowe, inicjatywy zwane hackerspace (miejsca, gdzie spotykają się ludzie dzielący wspólne zainteresowania, najczęściej informatyczne) oraz otwarte platformy edukacyjne online (np. skillshare.com).

Inny podział zaproponowała R. Botsman. Podzieliła ona wspólną konsumpcję $e^{3}$ na trzy kategorie [Botsman 2017] ${ }^{4}$ :

1) rynki redystrybucji (mają one na celu przedłużenie cyklu życia produktu i redukowanie odpadów),

2) współdzielony styl życia (dzielenie się pieniędzmi, umiejętnościami oraz czasem),

3) wynajem dóbr (użytkownik płaci jedynie za korzyści produktu bez konieczności posiadania go na własność; największy potencjał mają produkty używane bardzo rzadko, np, wiertarka używana średnio przez ok. 12-13 minut w ciągu całego cyklu życia).

${ }^{2}$ Większość usług, jakie oferują te platformy, nie spełnia jednak kryteriów gospodarki współdzielenia ze względu na ich komercyjny charakter (jedynie portal Freecycle zachowuje formę non profit, oferując użytkownikom możliwość darmowej wymiany dóbr).

${ }^{3}$ Niekiedy pojęcia sharing economy oraz collaborative consumption używane są jako synonimy, a niekiedy collaborative consumption uznaje się za pojęcie węższe.

${ }^{4} \mathrm{R}$. Botsman oraz R. Rogers opisują to zagadnienie szerzej w pracy pt. What's Mine Is Yours: The Rise of Collaborative Consumption [2010]. 
Ponadto istnieje podział gospodarki współdzielenia ze względu na typ platformy - na for profit (FP) i non profit (NP), oraz typ dostawcy danego dobra bądź usługi - na peer-to-peer (P2P) i business-to-peer (B2P) [Schor 2014, s. 5]. C. Codagnone i B. Martens [2016, s. 12] przedstawiają powyższą klasyfikację w postaci matrycy, ukazującej, które rozwiązania stanowią właściwą gospodarkę współdzielenia, a które w dużej mierze wykorzystują jedynie jej marketingowy potencjał.

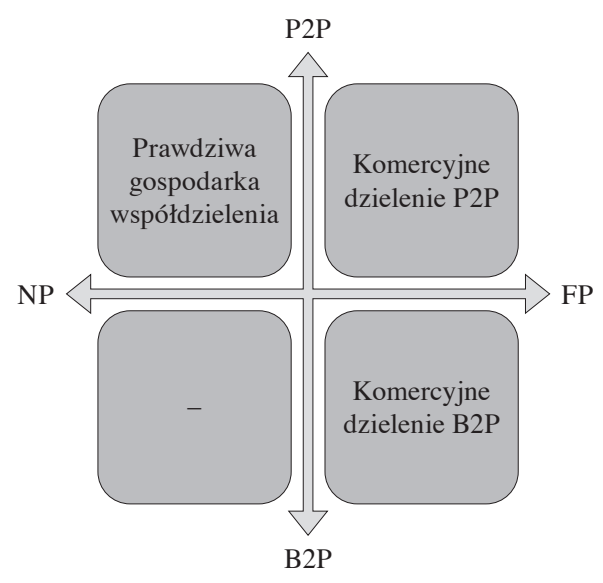

Rys. 1. Matryca gospodarki współdzielenia

Źródło: [Codagnone i Martens 2016].

Jak trafnie wskazują C. Codagnone i B. Martens, właściwa gospodarka współdzielenia jest terminem znacznie węższym niż wszystko to, co znamy obecnie pod pojęciem sharing economy. Na podstawie analizy matrycy można stwierdzić, że jedną z kluczowych cech właściwej gospodarki współdzielenia (we wprowadzeniu do niniejszej pracy nazwanej bezinteresowną) jest pewnego rodzaju kompromis oraz zwiększone zaangażowanie stron transakcji. Użytkownicy dają coś od siebie i w zamian coś otrzymują. Bezinteresownie dzielą się nadwyżką posiadanego zasobu i zaspokajają tym samym część rynkowego popytu. Nie wszystkie usługi oferowane przez korporacje okrzyknięte mianem sharing economy są jednak takimi w rzeczywistości. Jak podkreśla J. Schor [2014, s. 1], firmy chcą być kojarzone z gospodarką współdzielenia ze względu na jej pozytywny wizerunek wzmacniany dodatkowo innowacyjnością i atrakcyjnością nowych technologii.

Aby ukazać bardzo dużą skalę działalności ekonomicznej prowadzonej w ramach sharing economy, w tabeli 1 przedstawiono najpopularniejsze platformy $\mathrm{z}$ uwzględnieniem podziału na sektory. 
Tabela 1. Platformy w gospodarce współdzielenia

\begin{tabular}{|c|c|c|}
\hline Sektor & Nazwa & Opis działalności \\
\hline \multirow{3}{*}{$\begin{array}{l}\text { Usługi } \\
\text { transportowe }\end{array}$} & Uber & Usługi transportowe na żądanie \\
\hline & Lyft & Usługi transportowe na żądanie \\
\hline & Gett & Usługi transportowe na żądanie \\
\hline \multirow[t]{3}{*}{$\begin{array}{l}\text { Dzielenie } \\
\text { pojazdów }\end{array}$} & Zipcar & $\begin{array}{l}\text { Krótkoterminowa wypożyczalnia samochodów (należy } \\
\text { do Avis Budget Group) }\end{array}$ \\
\hline & Sharoo & $\begin{array}{l}\text { Dzielenie się posiadanym samochodem na godziny lub } \\
\text { dni, a także długoterminowo }\end{array}$ \\
\hline & Traficar & $\begin{array}{l}\text { Wypożyczanie samochodu na minuty (usługa dostępna } \\
\text { w Krakowie) }\end{array}$ \\
\hline \multirow[t]{4}{*}{$\begin{array}{l}\text { Dzielenie } \\
\text { przestrzeni }\end{array}$} & Share Desk & $\begin{array}{l}\text { Wynajmowanie przestrzeni biurowych (zarówno na } \\
\text { krótki, jak i długi okres) }\end{array}$ \\
\hline & We work & Wynajmowanie przestrzeni biurowych \\
\hline & Couchsurfing & $\begin{array}{l}\text { Oferowanie darmowego zakwaterowania i korzystanie } \\
\text { z niego }\end{array}$ \\
\hline & Airbnb & Wynajmowanie przestrzeni własnego domu \\
\hline \multirow[t]{3}{*}{ Crowdfunding } & Kickstarter & Platforma finansowania społecznościowego \\
\hline & Indiegogo & Platforma finansowania społecznościowego \\
\hline & Polak potrafi & Platforma finansowania społecznościowego w Polsce \\
\hline \multirow[t]{2}{*}{$\begin{array}{l}\text { Platformy } \\
\text { edukacyjne }\end{array}$} & Coursera & $\begin{array}{l}\text { Kursy online (wiele z nich to kursy renomowanych } \\
\text { uniwersytetów, które mogą zakończyć się uzyskaniem } \\
\text { certyfikatu) }\end{array}$ \\
\hline & Khanacademy & Darmowe kursy i lekcje \\
\hline \multirow{2}{*}{$\begin{array}{l}\text { Dzielenie się } \\
\text { przedmiotami/ } \\
\text { wymiana }\end{array}$} & Hey, neighbor & $\begin{array}{l}\text { Dzielenie się przedmiotami i wymienianie się nimi } \\
\text { w społecznościach lokalnych }\end{array}$ \\
\hline & Rent the runway & $\begin{array}{l}\text { Wypożyczanie ubrań za miesięczną stałą opłatę bądź } \\
\text { jednorazowo za sztukę }\end{array}$ \\
\hline \multirow{2}{*}{$\begin{array}{l}\text { Zdrowie } \\
\text { i medycyna }\end{array}$} & Crowdmed & Diagnozowanie chorób online \\
\hline & Be my eyes & $\begin{array}{l}\text { Aplikacja, która pozwala niewidomym skontaktować } \\
\text { się z widzącym użytkownikiem, który dzięki kamerze } \\
\text { w telefonie opisuje to, co niewidomy chciałby zobaczyć }\end{array}$ \\
\hline \multirow[t]{3}{*}{ Jedzenie } & $\begin{array}{l}\text { The Food } \\
\text { Assembly }\end{array}$ & $\begin{array}{l}\text { Sieć społeczności łącząca lokalnych producentów bez- } \\
\text { pośrednio z konsumentami }\end{array}$ \\
\hline & Kitchen Surfing & $\begin{array}{l}\text { Usługa polegająca na tym, że zawodowy kucharz przy- } \\
\text { chodzi gotować do domów użytkowników }\end{array}$ \\
\hline & Uber eats & Dostarczanie zamówień z restauracji do domów \\
\hline \multirow[t]{2}{*}{ Uroda } & My Glamm & Usługi kosmetyczne i SPA \\
\hline & Be Glammed & Usługi makijażystek i fryzjerów \\
\hline
\end{tabular}

Źródło: opracowanie własne na podstawie stron internetowych podanych platform. 
Promując gospodarkę współdzielenia jako sposób na lepsze i bardziej efektywne wykorzystanie zasobów, korporacje bardzo często uzyskują jedynie dodatkowy kanał sprzedaży swoich usług, który dla odbiorców finalnych niczym nie różni się od tradycyjnej konsumpcji. Analizując usługi Ubera i Airbnb, jednych z najbardziej rozpoznawalnych firm oferujących rozwiązania wpisujące się w gospodarkę współdzielenia, warto zwrócić uwagę na dwa przypadki.

Główny profil działalności Ubera stanowi kojarzenie kierowców oraz pasażerów za pomocą mobilnej aplikacji. Usługi firmy można podzielić na trzy rodzaje5:

- UberPOP, UberX, UberXL, UberSELECT (podstawowa usługa Ubera),

- UberBLACK, UberSUV, UberLUX (przejazdy samochodami luksusowymi),

- UberPOOL (wspólne przejazdy i podział kosztów z innym pasażerem, który jedzie w tym samym kierunku).

Pierwsze dwie usługi oferowane przez Ubera nie różnią się zbytnio od standardowej usługi taksówkarskiej, wyróżnia je jedynie alternatywny kanał dotarcia do potencjalnych pasażerów. Trzecia usługa, kojarząca ludzi jadących w tym samym kierunku, wydaje się wpisywać w gospodarkę współdzielenia, ale również nie jest pozbawiona nastawienia na zysk.

Airbnb za pomocą specjalnej platformy umożliwia udostępnienie przestrzeni swojego domu innym użytkownikom. Oferuje trzy rodzaje usług (www.airbnb. com, data dostępu: 15.03.2017):

- wynajęcie całego domu,

- wynajęcie pokoju prywatnego,

- współdzielenie pokoju z osobą trzecią.

Podobnie jak w przypadku Ubera tylko ostatnia usługa, czyli współdzielenie pokoju, spełnia kryteria gospodarki współdzielenia. Bardzo często wynajęcie całego domu bądź pokoju (o ile nie jest to tylko wynajmowanie podczas nieobecności mieszkańców) jest standardową usługą hotelarską, dla której Airbnb udostępnia platformę pośredniczącą w transakcji.

Analizując powyższe przykłady, można stwierdzić, że niezwykle istotny w opisywanej formie gospodarowania jest właśnie wspomniany wcześniej kompromis. $Z$ właściwą gospodarką współdzielenia mamy do czynienia wówczas, gdy zwiększa się intensywność wykorzystania zasobów już posiadanych bez konieczności angażowania nowych. Strony transakcji są w stanie zrezygnować z części swoich interesów, aby równocześnie mógł zostać zaspokojony popyt innych uczestników rynku.

5 Typy usług mogą się różnić w zależności od miasta. Na terenie Krakowa działają obecnie UberPOP oraz UberSELECT (www.uber.com, data dostępu: 15.03.2017). 


\section{3. Źródła rosnącej popularności gospodarki współdzielenia}

Powodów korzystania z rozwiązań gospodarki współdzielenia może być wiele. Dużą liczbę użytkowników przyciąga atrakcyjność technologiczna platform, które traktują oni jako pewnego rodzaju nowinki. Istotne są również czynniki ekonomiczne, środowiskowe oraz społeczne [Schor 2014, s. 5]. Jednocześnie konsumentom coraz rzadziej zależy wyłącznie na produkcie, a częściej na korzyściach, jakie ten produkt daje. Rezygnują więc z jego posiadania, zaspokajając główne potrzeby i unikając przy tym dodatkowych obciążeń. Pojawiające się nowe platformy oferujące usługi w ramach gospodarki współdzielenia na początku XXI w. są wynikiem splotu rozmaitych czynników ekonomicznych i społecznych. W ocenie autorki, jeśli chodzi o czynniki wpływające na rosnącą popularność gospodarki współdzielenia, na szczególną uwagę zasługują:

- rozwój nowych technologii (zwłaszcza technologii mobilnych) i rewolucja cyfrowa,

- kryzys finansowy 2007/2008 i zmiana w postrzeganiu konsumpcji,

- zmiana społeczna (większe zaufanie społeczne oraz większa świadomość dotycząca zrównoważonego rozwoju i problemu wyczerpywania się zasobów).

Głębokie transformacje technologiczne przyczyniają się do rozwoju gospodarki współdzielenia. Dzięki nowym rozwiązaniom, które zawdzięczamy ostatniej rewolucji informatycznej, dzielenie stało się prostsze niż kiedykolwiek. Technologia pozwala ludziom dostawać od siebie nawzajem to, czego potrzebują. Jak podaje J. Schor [2014, s. 2], zaawansowane technologicznie oprogramowanie zmniejszyło w znacznym stopniu wysokie niegdyś koszty transakcyjne rynków wtórnych. Informacje dotyczące reputacji sprzedających zasadniczo obniżyły ryzyko związane z przeprowadzeniem transakcji z nieznajomym. Transakcje te stały się również dużo prostsze ze względu na dostępność wielu zasobów w sieci [Hamari, Sjoklint i Ukkonen 2015, s. 2]. Wiele możliwości dało także powstanie Web 2.0 (podstawą jej działalności są treści tworzone przez jej użytkowników), pojawienie się oprogramowania Open Source (oprogramowanie z wolnym dostępem do kodu źródłowego) oraz inicjatyw takich jak Wikipedia czy edukacja online Massive Open Online Courses (MOOC) [Belk 2014, s. 1596]. Ponadto wiele rozwiązań tworzonych przez nowe przedsiębiorstwa opiera się na technologii peer-to-peer, która ma ogromny potencjał. Dzięki takim rozwiązaniom pobudzana jest nowa forma konsumpcji, zwiększa się produktywność i efektywność, a także nacisk na innowacyjność przedsiębiorstw [Sandararajan 2014, s. 1]. Wielkie zmiany, jakie niesie ze sobą cyfrowa rewolucja, sprawiają, że niemożliwe staje się przewidzenie tempa i kierunku jej rozwoju. W dobie rosnących cen paliw kopalnych, zwiększania się zanieczyszczenia środowiska oraz wyczerpywania zasobów naszej planety rozwiązania możliwe do zastosowania dzięki cyfrowym technologiom 
kreują nową jakość dającą szansę na zrównoważony rozwój w pełnym tego słowa znaczeniu.

Kryzys finansowy jako jedno z ważniejszych wydarzeń ekonomicznych obecnego stulecia wywołał pewnego rodzaju przesilenie oraz przyczynił się do powstania alternatywnego podejścia zarówno do konsumpcjonizmu, jak i do systemu gospodarczego, jakim jest kapitalizm. W dyskursie politycznym i społecznym na znaczeniu zyskały nie tylko postulaty dotyczące konieczności naprawy szeroko pojętych regulacji istniejącego systemu, ale także koncepcje związane ze wspólną konsumpcją i gospodarką współdzielenia [Heinrisch 2013, s. 229]. Kryzys finansowy, który dotknął znaczną część społeczeństwa zachodniego, zachwiał poczuciem pewności dobrobytu klasy średniej. Stabilne zatrudnienie dla wielu zmieniło się $\mathrm{w}$ pracę na zlecenie, co wymusiło poszukiwanie alternatywnych form konsumpcji. Wzrastające zadłużenie i nadmierna konsumpcja pompowały bańkę, która w końcu musiała pęknąć. W 2007 r. stało się jasne, z jak wieloma problemami boryka się współczesny świat. Ten trudny okres, jakim był koniec pierwszej dekady XXI w., zbiegł się w czasie z dynamicznym rozwojem nowych technologii, dzięki którym na rynku pojawiło się wiele przedsiębiorstw oferujących swoje usługi oparte na formach współdzielenia.

Jeśli chodzi o zmianę społeczną, pojawia się pewna nowa jakość międzyludzkich relacji. Niegdyś dzielenie się było zarezerwowane dla bardzo wąskiej grupy bliskich nam osób [Schor 2014, s. 7]. Jest to argument przeciw poglądowi, że sharing economy to nic nowego, a ludzie dzielili się od zawsze. $\mathrm{Z}$ tym ostatnim nie sposób się nie zgodzić, ale obserwując wzrost zaufania oraz złożoności relacji między osobami zupełnie sobie obcymi, należy stwierdzić, że gospodarka współdzielenia jest czymś nowym. R. Belk [2014, s. 1596] wskazuje na znaczący podział pomiędzy sharing in a sharing out. Pierwsze zjawisko (inclusive act) dotyczy przede wszystkim grona bliskich znajomych oraz rodziny (zjawisko to badali już w latach 70. XX w. M. Felson i J. Spaeth), podczas gdy drugie wychodzi poza te ramy i obejmuje dzielenie się pomiędzy nieznajomymi sobie osobami. Internetowe platformy wraz z kompleksowym narzędziem, jakim są systemy reputacyjne umożliwiające ocenianie użytkowników (co w dużej mierze stanowi przedmiot badań informatyki społecznej), stworzyły możliwości, które wcześniej nie były dostępne. J. Schor [2014, s. 8] odwołuje się w tym aspekcie do pojęcia z pogranicza psychologii kognitywnej i socjologii, tj. do tzw. mądrości tłumu. Dzięki niej opinia dużej liczby osób jest uśredniana, a co za tym idzie - niwelowany jest szum informacyjny, na który bardziej narażeni są pojedynczy eksperci. Ponadto rosnący wskaźnik urbanizacji (przewiduje się, że do 2050 r. ok. 70\% społeczności liczącej ponad 9 mld będzie mieszkać w miastach) również sprzyja powstawaniu nowych form gospodarki współdzielenia. Miasta ze względu na dużą gęstość zaludnienia i ograniczoną ilość pewnych zasobów stanowią naturalne środowisko rozwoju alternatywnych 
form konsumpcji i rezygnacji z posiadania na rzecz dostępu [Sundararajan 2014, s. 4]. J. Hamari, M. Sjoklint i A. Ukkonen [2015, s. 9] przeprowadzili kompleksową analizę powodów uczestnictwa społeczeństwa we wspólnej konsumpcji. Z badań wynika, że rozwiązania te angażują przede wszystkim konsumentów najbardziej świadomych ekologicznych i środowiskowych problemów świata. Zmiana społeczna, polegająca zarówno na chęci dzielenia się z nieznajomymi, jak i na zwiększającej się świadomości, stanowi fundament rozwiązań gospodarki współdzielenia, bez których jej potencjał byłby znacznie ograniczony.

\section{Gospodarka współdzielenia a (nie)zrównoważony rozwój}

Obecnie obserwuje się coraz większą potrzebę opracowania nowej zrównoważonej ścieżki rozwoju gospodarek państw. Analizując zagadnienie rozwoju, coraz częściej przywołuje się inne niż PKB wskaźniki, które odzwierciedlałyby poziom życia mieszkańców, a przede wszystkim jego jakość [Heinrisch 2013, s. 229]. Pod wpływem narastającego zaniepokojenia o ekologiczny ślad działalności człowieka ${ }^{6}$ zmieniło się także w ostatnich latach nastawienie do konsumpcji [Hamari, Sjoklint i Ukkonen 2015, s. 1]. Gospodarka współdzielenia, najbardziej rozwinięta w Stanach Zjednoczonych i Europie Zachodniej, staje się zjawiskiem coraz bardziej widocznym w skali globalnej. Idea dzielenia, w którą wpisane jest dążenie do zrównoważonych i bardziej sprawiedliwych społecznie rozwiązań, sprawdza się na całym świecie. Nie tylko europejskie stolice są centrami rozwiązań gospodarki współdzielenia [Schor 2014, s. 2]. Przykładowo rząd Ekwadoru uruchomił już w 2013 r. program Buen Conocer, inicjatywę promującą sharing economy (www. floksociety.org). Opis przywołanego projektu w sposób bardzo trafny oddaje najważniejsze cechy gospodarki współdzielenia: „Rewolucja wiedzy, której fundamentami są innowacja, nauka i technologia, prowadzi do diametralnych zmian w sposobie produkcji i konsumpcji, jaki dzisiaj obserwujemy. Takie transformacje sprawią, że kraj przejdzie z fazy uzależnienia od ograniczonych i skończonych zasobów do fazy zasobów nieograniczonych, jakimi są właśnie nauka i technologia"7. Takie podejście spotykane jest coraz częściej, a rządzący widzą w gospodarce współdzielenia nowe możliwości i potencjał rozwoju dla swoich państw.

${ }^{6}$ Ślad ekologiczny to miara zapotrzebowania człowieka na zasoby naturalne. Zgodnie z definicją World Wild Fund for Nature ślad ekologiczny mierzony jest w hektarach globalnych, które szacują zasoby Ziemi w stosunku do możliwości ich odtworzenia przez naszą planetę. Zob. www. wwf.pl/co_robimy/living_planet_report/living_planet_report_2014/lad_ekologiczny (data dostępu: 3.04.2017).

7 Tłumaczenie własne na podstawie: Buen Conocer, www.floksociety.org/que-es-esto (data dostępu: 13.03.2017). 
Wielu zwolenników gospodarki współdzielenia dopatrywało się w niej szans związanych z ochroną środowiska, tworzeniem bardziej zrównoważonego i świadomego modelu konsumpcji oraz rosnącymi możliwościami zwykłych obywateli. Głosy te były szczególnie silne po niszczącym dla gospodarek wielu krajów kryzysie finansowym [Schor 2014, s. 8]. Obecnie ze względu na tzw. korporatyzację wielu czołowych graczy rynku gospodarki współdzielenia jej zasługi na rzecz zrównoważonego i trwałego rozwoju mogą zostać zakwestionowane [Schor 2014, s. 2]. Największe kontrowersje wzbudzają jednak platformy for profit, które niekiedy w sposób rażący i widoczny wykorzystują luki związane z przepisami prawa pracy oraz podatkami. Niektóre oferowane przez platformy współdzielenia usługi są zwykłymi usługami, nie mają nic wspólnego z definicją dzielenia się, jaka jest nam znana. Działania takie obniżają rangę i wartość całego ruchu sharing economy. Firmy wprowadzają w błąd użytkowników, którzy przekonani, że dokonują bardziej świadomego i lepszego wyboru, tak naprawdę przyczyniają się do kumulowania zysków wielkich korporacji.

Należy jednak pamiętać, że złożoność zjawiska, jakim jest sharing economy, oraz jego występowanie w wielu sektorach (czasem bardzo trudnych do porównania) nie pozwala go w sposób jednoznaczny ocenić. Do bardziej optymistycznych wniosków można dojść, gdy analizie poddaje się rozwiązania gospodarki współdzielenia tylko od strony konsumpcyjnej. Nie wymaga potwierdzenia fakt, że korzystanie z noclegów w domach należących do innych ludzi zmniejsza popyt na nowe hotele, a dzielenie się przedmiotami lub narzędziami z sąsiadami obniża poziom zakupów tych dóbr w sklepach. Korzystanie z takich rozwiązań zwiększa także społeczną odpowiedzialność i świadomość wyczerpujących się zasobów otaczającego nas świata. Pojawiają się także głosy socjologów oraz antropologów, którzy koncepcję jednostki zwaną homo collaborans przeciwstawiają ugruntowanemu we współczesnej teorii ekonomii homo oeconomicus [Heinrisch 2013, s. 229].

Nie zostały jednak przeprowadzone kompleksowe badania, które opisywałyby dokładnie wpływ, jaki gospodarka współdzielenia ma na rynki, a także na stopień wykorzystania zasobów. Kwestia ta jest niezwykle złożona, ponieważ nieznana jest struktura przyszłych wydatków konsumentów, którzy aktywnie uczestniczą w tych rozwiązaniach [Schor 2014, s. 6]. Być może dodatkowe pieniądze, jakimi dysponują dzięki wynajmowaniu kanapy w pokoju gościnnym, są przeznaczane na cele, które mogą przyczynić się do większej eksploatacji zasobów naszej planety. Powstaje np. pytanie, czy skoro podróżowanie dzięki Airbnb stało się tańsze, to podróżuje więcej osób, zwiększając tym samym ślad ekologiczny. Te i podobne kwestie pozostają otwarte, a rosnąca popularność gospodarki współdzielenia bez wątpienia prędzej czy później sprawi, że będą one stawiane w sposób bardziej świadomy. 
Aby gospodarka współdzielenia nie straciła swojego dobroczynnego wpływu na zmieniający się model konsumpcji, niewątpliwie istotne i naglące stało się obecnie unormowanie kwestii związanych z prawem pracy i podatkami, które wzbudzają najwięcej kontrowersji. Nowe technologie stanowią jedynie narzędzie, które nieuregulowane może być przyczyną nadużyć ze strony uczestników transakcji. Warto temu zapobiegać, ponieważ zwiększająca się świadomość społeczna połączona z możliwościami, jakie daje gospodarka współdzielenia, może mieć zbawienne skutki dla kończących się zasobów naszej planety.

\section{Zakończenie}

Pojęcie sharing economy jest niezwykle złożone i pojemne, a ponadto brak jednoznacznych rozstrzygnięć co do jego zakresu i znaczenia, co bez wątpienia przyczynia się do trwania sporu między zwolennikami a przeciwnikami tej formy gospodarowania. Entuzjaści często nie dostrzegają negatywnych skutków współdzielenia. Z kolei przeciwnicy podchodzą do niego czasem zbyt krytycznie, skupiając się na wielkich korporacjach, które zyskały ostatnio popularność. Nie należy jednak zapominać, że gospodarka współdzielenia to nie tylko Uber i Airbnb, lecz alternatywna forma gospodarowania i konsumpcji [Belk 2014, s. 1598], która daje wiele możliwości, a od samych użytkowników i twórców konkretnych rozwiązań zależy, jak będą one wykorzystane. Podstawowym kryterium podziału gospodarki współdzielenia powinien być jej komercyjny bądź niekomercyjny charakter. Takie rozróżnienie pozwoli dużo wyraźniej dostrzec potencjał, jaki posiada gospodarka współdzielenia, oraz zwrócić uwagę na to, że pojawiające się zarzuty i oskarżenia dotyczą organizacji nastawionych na zysk.

Otwarte pozostaje pytanie, w jaki sposób zjawisko gospodarki współdzielenia może zostać wyjaśnione przez istniejące teorie ekonomii. Zrozumienie alternatywnych form własności daje duże możliwości, jeśli chodzi o badania naukowe zarówno od strony popytowej (relacje peer-to-peer), jak i podażowej (wspólna produkcja, innowacje) [Heinrisch 2013, s. 230]. Istotna z punktu widzenia teorii ekonomii wydaje się także oparta na zaufaniu transakcja (jeden z głównych elementów teorii ekonomii instytucjonalnej), która posiada szczególne znaczenie w gospodarce współdzielenia. Złożoność zjawiska, jakim jest sharing economy, rola kapitału społecznego oraz koncepcja homo collaborans bez wątpienia przyciągnie także wielu badaczy nie tylko nauk ekonomicznych, ale również nauk psychologicznych i socjologicznych. Podsumowując, podejście to ma duży potencjał, który dzięki rosnącej popularności z pewnością zostanie wykorzystany. Obecnie ze względu na wczesne stadium rozwoju bardzo trudno jest przewidzieć, w którym kierunku rozwinie się gospodarka współdzielenia. Rodzą się pytania: 
czy wymierzona w nią krytyka wywoła reakcję ze strony rządów polegającą na regulacji (bądź deregulacji) pewnych kwestii? czy nowe rozwiązania będą służyć wspieraniu zrównoważonego rozwoju? czy rosnąca świadomość społeczeństwa na temat wyczerpujących się zasobów Ziemi doprowadzi do wyraźnego i świadomego przeciwstawienia się hiperkonsumpcji? Bez wątpienia odpowiedzi na te pytania przyniosą kolejne lata, a ożywiony dyskurs polityczny i społeczny będzie miał duży wpływ na przyszłość gospodarki współdzielenia.

\section{Literatura}

Bardhi F., Eckhardt G. [2012], Access-Based Consumption: The Case of Car Sharing, „Journal of Consumer Research”, vol. 39, nr 4, https://doi.org/10.1086/666376.

Belk R. [1988], Possessions and the Extended Self, „Journal of Consumer Research”, vol. 15, nr 2, https://doi.org/10.1086/209154.

Belk R. [2007], Why Not Share Rather Than Own?, „Annals of the American Academy of Political and Social Science", vol. 611, nr 10, https://doi.org/10.1177/0002716206298483.

Belk R. [2010], Sharing, „The Journal of Consumer Research”, vol. 36, nr 5, https://doi. org/10.1086/612649.

Belk R. [2013], Extended Self in a Digital World, „Journal of Consumer Research”, vol. 40, nr 3, https://doi.org/10.1086/671052.

Belk R. [2014], You Are What You Can Access: Sharing and Collaborative Consumption Online, ,Journal of Business Research”, vol. 67, nr 8, https://doi.org/10.1016/j.jbusres. 2013.10.001.

Benkler Y. [2005], Sharing Nicely: On Shareable Goods and the Emergence of Sharing as a Modality of Economic Production, „The Yale Law Journal”, vol. 114, nr 2, https:// doi.org/10.2307/4135731.

Botsman R. [2017], The Case for Collaborative Consumption, www.rachelbotsman.com/ work/the-case-for-collaborative-consumption (data dostępu: 15.03.2017).

Botsman R., Rogers R. [2010], What's Mine is Yours: The Rise of Collaborative Consumption, Harper Collins, New York.

Codagnone C., Martens B. [2016], Scoping the Sharing Economy: Origins, Definitions, Impact and Regulatory Issues, Digital Economy Working Paper 2016/01 JRC100369, Institute for Prospective Technological Studies, Seville.

Felson M., Spaeth J. [1978], Community Structure and Collaborative Consumption: A Routine Activity Approach, ,American Behavioral Scientist”, vol. 21, $\mathrm{nr} 4$, https:// doi.org/10.1177/000276427802100411.

Gansky L. [2010], The Mesh, Why the Future of Business is Sharing, Penguin Group, London.

Hamari J., Sjoklint M., Ukkonen A. [2015], The Sharing Economy: Why People Participate in Collaborative Consumption, ,Journal of Association for Information Science and Technology", vol. 67, nr 9, https://doi.org/10.1002/asi.23552.

Heinrisch H. [2013], Sharing Economy: A Potential New Pathway to Sustainability, „GAIA - Ecological Perspectives for Science and Society”, vol. 22, nr 4, https://doi. org/10.14512/gaia.22.4.5. 
Lamberton C., Rose R. [2012], When is Our Better Than Mine?, „Journal of Marketing”, vol. 76, nr 4, https://doi.org/10.1509/jm.10.0368.

Ozanne L., Ballantine W. [2010], Sharing as a form of Anti-consumption? An Examination of Toy Library Users, ,, Journal of Consumer Behaviour”, vol. 9, nr 6, https://doi. org/10.1002/cb.334.

Petropoulos G. [2017], An Economic Review of the Collaborative Economy, http://bruegel.org/2017/02/an-economic-review-of-the-collaborative-economy (data dostępu: 3.03.2017).

Schor J. [2014], Debating the Sharing Economy, http://www.greattransition.org/publication/debating-the-sharing-economy (data dostępu: 13.03.2017).

Sundararajan A. [2014], Peer-to-peer Businesses and the Sharing (Collaborative) Economy: Overview, Economic Effects and Regulatory Issue, http://smallbusiness.house. gov/uploadedfiles/1-15-2014_revised_sundararajan_testimony.pdf (data dostępu: 13.03.2017).

\section{Sharing Economy - Concept, Origins and Potential}

(Abstract)

The paper presents a theoretical overview of definitions of the sharing economy. It emphasises the role of the access to goods and services, which are systematically taking the place of ownership. It refers to the main categorizations presented in the literature as well as the genesis of the concept. It presents the sharing economy as an alternative model of consumption, one which seeks to increase the efficiency of the resources creating new value for societies. This new value is largely possible through the digital revolution providing previously inaccessible tools, through new quality in interpersonal relationships as well as increasing social awareness. The aim of the paper is to provide a systematic review of the literature and to clarify the principle of true sharing as opposed to a profit-based orientation.

Keywords: sharing economy, collaborative consumption, hyperconsumption, sustainable development. 